\title{
鷄卵の貯藏印に於ける變化に就きて（第二報）
}

\author{
传々木林治郎 \\ 原澤 久去
}

（束京帝國大學農學部）

緒言

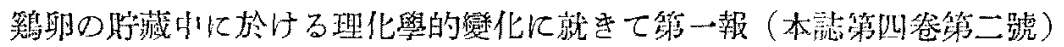

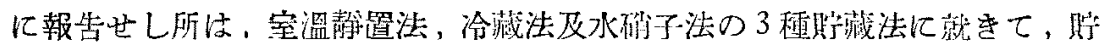
藏中，成分の理化學的變化並にビタミンCの保倞力を檢したる成縝にして， 其概要は次の如くでする。

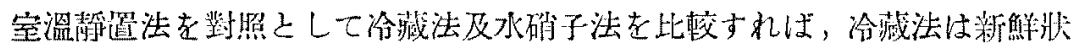

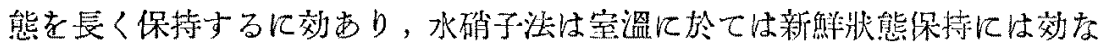
けれども防腐には有効极るて上を認めた。而して渝藏せるものは一旦溫度上

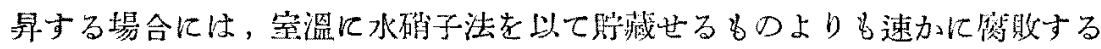
ことを認めた。

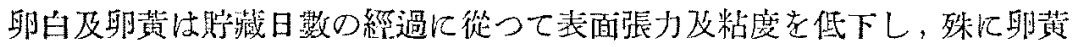

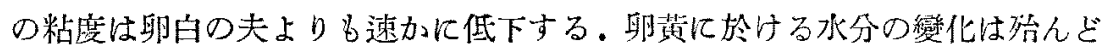
認められ好が，卵白の水分は㭙藏中に漸次減少する. Alcohol 可溶性空素， Amino 態空素及無機態燐は落しく增加し，蛋白質態空素及燐は減少する。之 れ蛋白質の分解を示するのにして，而か子粘度の低下と蛋白質の分解とは密 接なる關係にあること及鵎卵のビタミンC は，室温に150日間眝藏せるもの に於てを有效记存すること孝確好を。

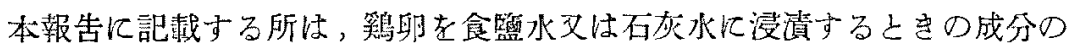
理化學的變化を探笢し，以て雨法が眝藏法又は加工法として應用し得るや石 やを知らんが䉆めに䆩驗せる成績である。

實驗

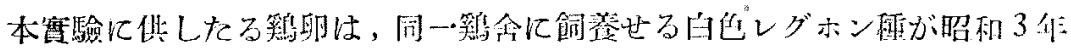




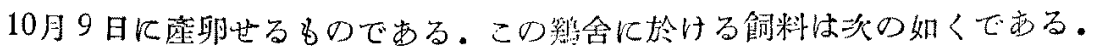
第一表合司料口配合

\begin{tabular}{|c|c|c|c|c|c|}
\hline \multicolumn{3}{|c|}{ 觛 料（容急比） } & 胡 & 畫 & 夕 \\
\hline \multirow{3}{*}{$\begin{array}{l}\text { 癷 } \\
\text { 小 } \\
\text { 大 }\end{array}$} & \multirow{4}{*}{$\begin{array}{l}\text { 豆 } \\
\text { 数 }\end{array}$} & \multirow{2}{*}{$\begin{array}{l}\text { 米 } \\
\text { 綮 }\end{array}$} & 2 & 2 & 3 \\
\hline & & & - & 3 & 3 \\
\hline & & \multirow[t]{2}{*}{ 粕 } & 3 & 2 & - \\
\hline & & & 8 & 5 & - \\
\hline I: & \multicolumn{2}{|c|}{ 罚 㯟 } & - & 3 & 3 \\
\hline \multirow{2}{*}{\multicolumn{3}{|c|}{$\begin{array}{c}\text { 出 } 大 \\
\text { 粐 }\end{array}$}} & 3 & - & - \\
\hline & & & - & - & 3 \\
\hline 高 & & 粱 & 4 & - & 7 \\
\hline
\end{tabular}

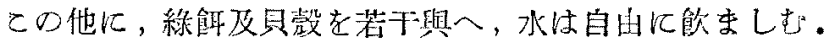
第一 败葴徒

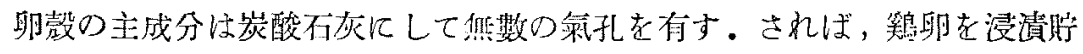

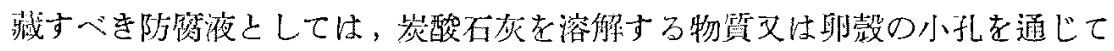
內部に浸入したる場合に, 衔生上危險なる物質は不適賞なること論ずる迄も ない。

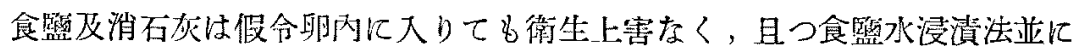

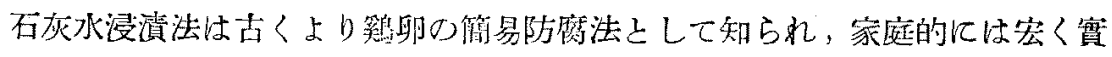

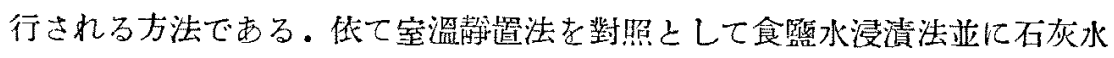

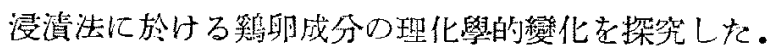

\section{A. 室溫靜置法}

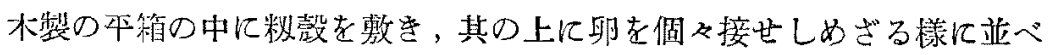
窒溫に塪置する。

B. 食監水浸漬涯

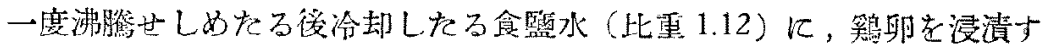

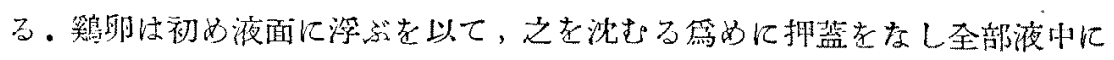

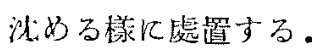

C. 石灰水浸留汪

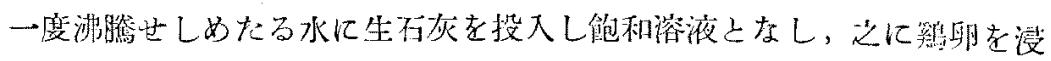




\section{漬する。}

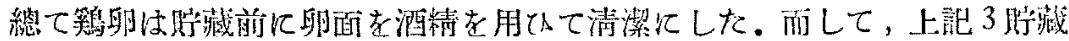

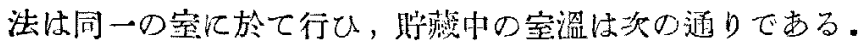

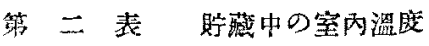

\begin{tabular}{|c|c|c|c|}
\hline 自月 & 至月 日 & 最高 & 最 \\
\hline 自10月15日 & 至10月31日 & $19^{\circ} \mathrm{C}$ & $13.5^{\circ} \mathrm{C}$ \\
\hline 11月 1 日 & 11月15日 & 21 & 11 \\
\hline " $16 \mathrm{~B}$ & " $30 \mathrm{~B}$ & 11 & 7.5 \\
\hline 12月 1 日 & 12月15日 & 11 & 6 \\
\hline$\prime \prime \quad 16$ 日 & $\prime \prime 31$ 日 & 12 & 2 \\
\hline 1月1日 & 1月 $15 \mathrm{H}$ & 9 & 1.5 \\
\hline
\end{tabular}

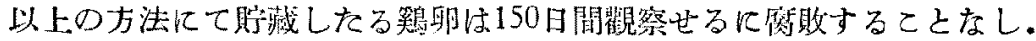

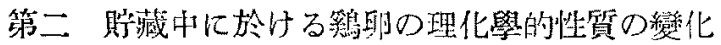

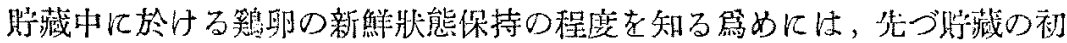

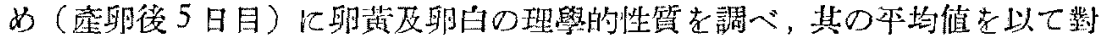
照值になし，之に對して睤藏中の變化を比較した。

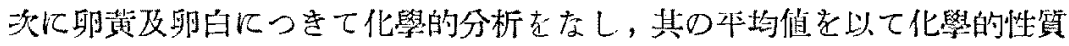
の髣化の歯照值とした。

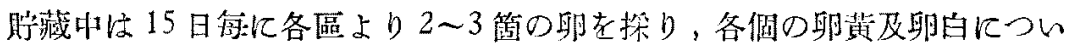
て理學的性筫を檢し，次んで化學的分析を行つた。

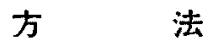

1. 試料の調製

第一報に同し。

2. 理化學的些筫D测定方法

(a) 表面張力の測定

第一報に同し。

(b) 粘度の测定

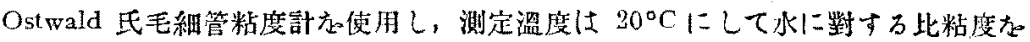
以て表はす。

（c）水分定量

第一報に问じ。 
(d) 全等絜0定提

第一報に同し。

(e) Alcohol 可浴性整素の定鼠

第一報に间し。

(f) 同上 Amino 態等絜の定最

Formol 滴定法に侤万。

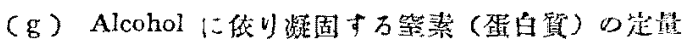

第一報に同し。

(h) 全橉の定量

第一報に京し。

(i) 類脂物質罌燐の定量

第一報に同し。

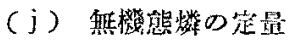

第一報に闹し。

(k) 食監の定量

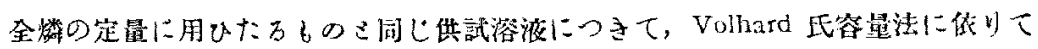

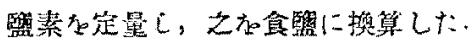

(1) 石灰の筀量

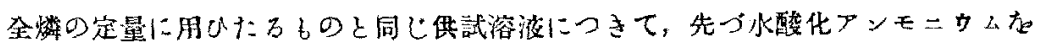
加人て中和し，次に醋酸方加へて酸性となし置き，葆酸アンモニウム杂加へて葆酸

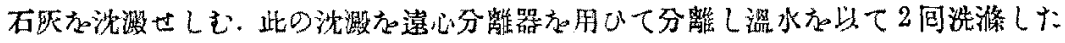

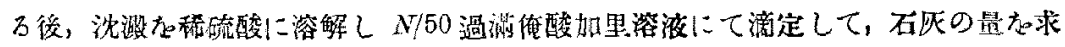
めた。

成 績

A) 表面張力の變化

䉆卵の貼藏中に於ける表面张力の變化は，测定の結果二次の表に示与通りで ある・

第 三 表 表面張力口綎化

卯黄

\begin{tabular}{|c|c|c|c|c|c|c|c|}
\hline 館藏法 & $\begin{array}{l}\text { 新鮮眆 } \\
\text { 對照偭 }\end{array}$ & 15 & 30 & 45 & 60 & 75 & 90 \\
\hline 䇪溫㲖睥法 & 44.80 & 43.20 & 89.25 & 40.25 & 44.50 & 40.15 & 38.00 \\
\hline 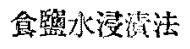 & & 42.50 & 51.90 & 59.00 & 87.20 & - & - \\
\hline 石灰水浸瀢法 & & 40.55 & 38.75 & 41.50 & 42.70 & 40.96 & 27.10 \\
\hline
\end{tabular}


卯白 $\bigcirc$ 部

\begin{tabular}{|l|l|l|l|l|l|l|l|}
\hline 室溫静置法 & 6090 & 53.90 & 46.60 & 50.00 & 50.50 & 50.12 & 45.75 \\
食緊水浸淡法 & & 51.90 & 48.50 & 51.25 & 49.40 & 47.26 & 44.42 \\
石灰水浸涉法 & & 46.70 & 46.80 & 42.00 & 51.50 & 42.36 & 43.80 \\
\hline
\end{tabular}

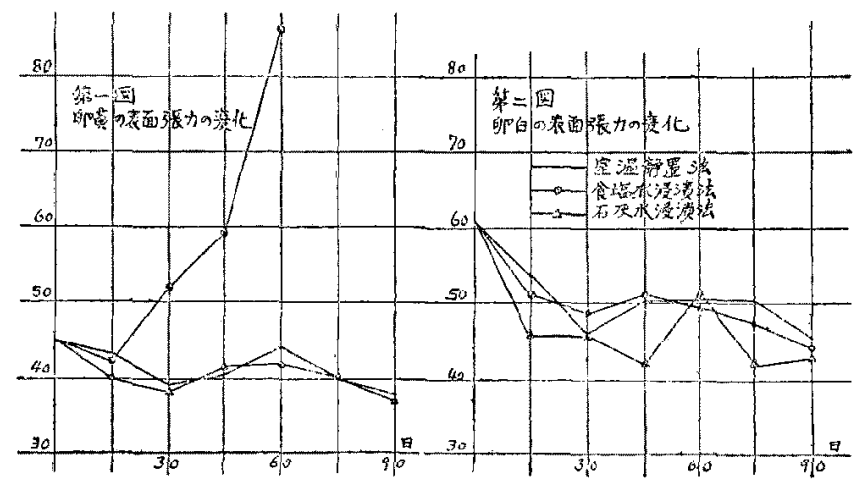

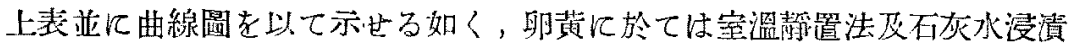

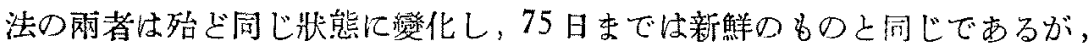
食㿼水浸漬法のbのは30日上り著しく、县する。

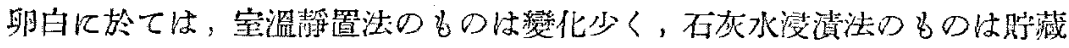
後 15 日にして萻しく低下し，其後は變化㮀めて少い。食留水浸清法の多の

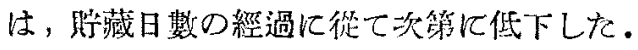

\section{B ）粘度の戀化}

鶄沺の䀧藏中に於ける粘度の變化は，测定の結果次に示す通りである。

$$
\begin{aligned}
& \text { 第 四表粘度の戀化 } \\
& \text { 留黉 の部 }
\end{aligned}
$$

\begin{tabular}{|c|c|c|c|c|c|c|c|}
\hline 眝苛藏法 & 對照值 & 15 & 30 & 45 & 60 & 75 & 90 \\
\hline 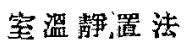 & 142.25 & 144.50 & 81.80 & 67.00 & 50.30 & 39.30 & 29.75 \\
\hline 食監水浸涀法 & & 340.20 & 1525.30 & - & - & - & - \\
\hline 石灰水浸清法 & & 90.30 & 42.40 & 80.90 & 86.00 & 37.30 & 25.30 \\
\hline
\end{tabular}


卯 白 9 部

\begin{tabular}{|c|c|c|c|c|c|c|c|}
\hline 堂溫静置法 & 9.84 & 6.75 & 6.90 & 4.90 & 7.25 & 6.01 & 4.80 \\
\hline 舍監水浸政法 & & 6.80 & 7.50 & 6.50 & 5.60 & 3.25 & 3.17 \\
\hline 石灰水浸清法 & & 9.10 & 8.30 & 10.70 & 5.60 & 5.35 & 3.75 \\
\hline
\end{tabular}
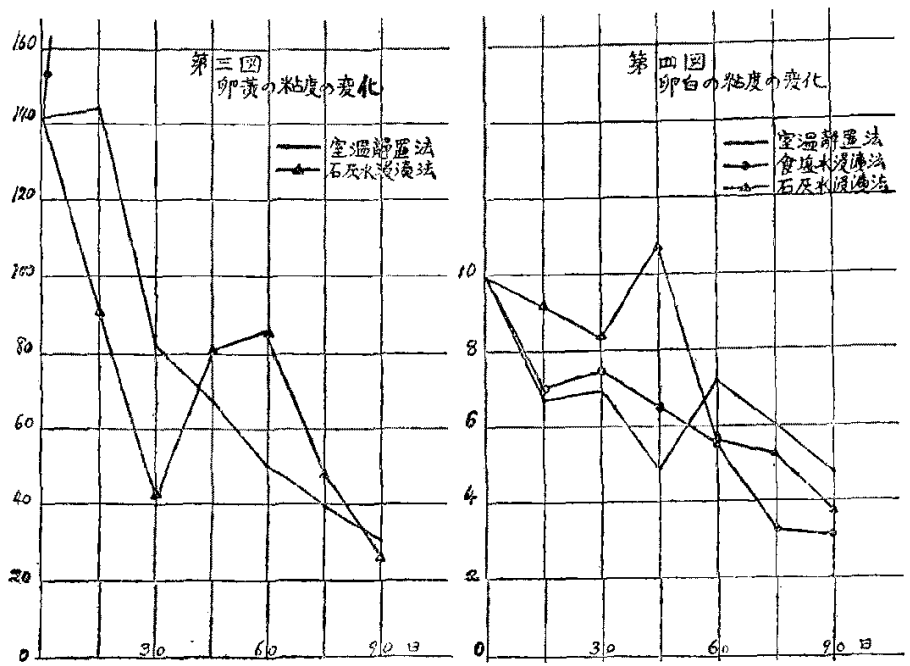

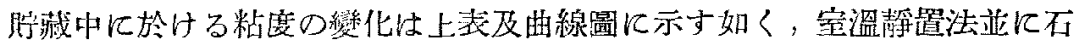

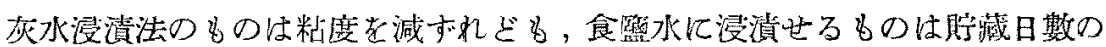
經過に從つて卵黄の粘度著しく垈加し，逐には凝固するに至る。

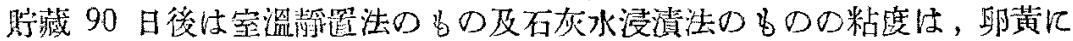

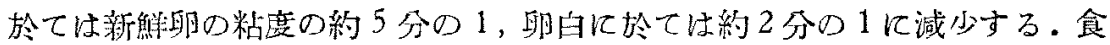

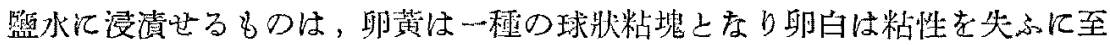
る。

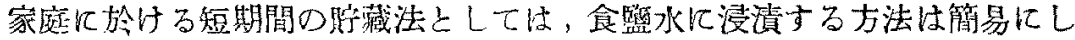

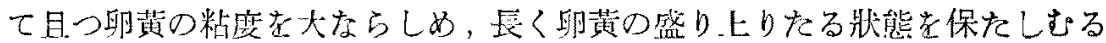

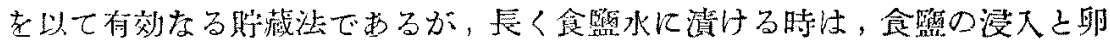

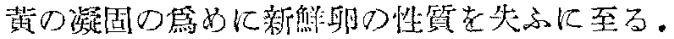

C) 水分の變化

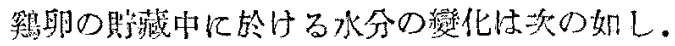




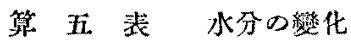

眆黄 0 部

\begin{tabular}{|c|c|c|c|c|c|c|c|}
\hline 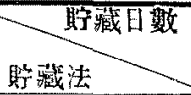 & 對照值 & 15 & 30 & 45 & $6 n$ & 75 & 90 \\
\hline 室泪静置法 & 49.05 & 49.23 & 50.94 & 51,83 & 51.51 & 52.37 & 52.50 \\
\hline 食嶇水浸清法 & & 48.01 & 44.31 & 43.63 & 37.83 & 27.17 & 25.96 \\
\hline 石灭水浸清法 & & 49.49 & 51.38 & 51.60 & 52.24 & 52.12 & 52.68 \\
\hline
\end{tabular}

明白 の 部

\begin{tabular}{|c|c|c|c|c|c|c|c|}
\hline 室溫静置法 & 87.38 & 86.78 & 86.44 & 86.87 & 86.10 & 86.60 & 86.20 \\
\hline 会監水浸漬法 & & 87.69 & 86.79 & 86.69 & 85.07 & 80.49 & 74.21 \\
\hline 石灰水浸涉法 & & 85.67 & 87.43 & 87.17 & 87.81 & 87.61 & 87.36 \\
\hline
\end{tabular}

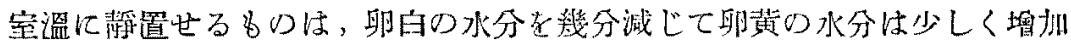
する。石㑞水に浸漬せるものは，卵白の水分變化なく卵黄の水分は少しく

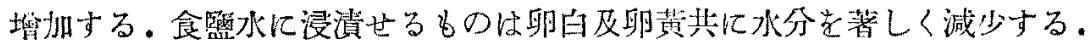
其代りに後記の如く，食監荐著しく堌加する，以上の理は自ら明加存ること なれば，說明の必要はない。

D）蛋白質の變化

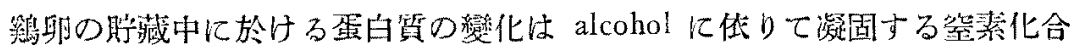

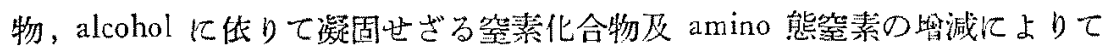

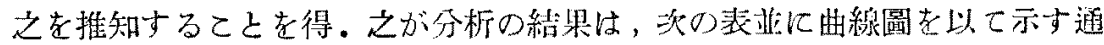
りである。

第 六 表 蛋白筫の䇾化 (固形哆 100 分中)

卯 舆 $の$ 部

\begin{tabular}{|c|c|c|c|c|c|c|c|}
\hline 賩藏法 & 對照值 & 15 & 30 & 45 & 60 & 75 & 90 \\
\hline 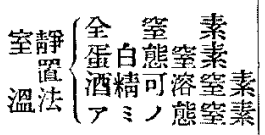 & $\begin{array}{l}5.346 \\
4.566 \\
0.780 \\
0.114\end{array}$ & $\begin{array}{l}5.280 \\
4.500 \\
0.780 \\
0.091\end{array}$ & $\begin{array}{l}5.332 \\
4.535 \\
0.797 \\
0.113\end{array}$ & $\begin{array}{l}5.272 \\
4.575 \\
0.697 \\
0.113\end{array}$ & $\begin{array}{l}5.685 \\
4.878 \\
0.807 \\
0.114\end{array}$ & $\begin{array}{l}5.348 \\
4.393 \\
0.955 \\
0.133\end{array}$ & $\begin{array}{l}5.576 \\
4.207 \\
1.369 \\
0.246\end{array}$ \\
\hline 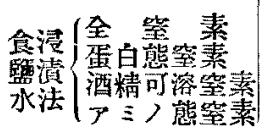 & & $\begin{array}{l}5.360 \\
4.713 \\
0.647 \\
0.116\end{array}$ & $\begin{array}{l}5.465 \\
4.826 \\
0.639 \\
0.172\end{array}$ & $\begin{array}{l}5.325 \\
4.629 \\
0.696 \\
0.097\end{array}$ & $\begin{array}{l}5.156 \\
4.476 \\
0.680 \\
0.103\end{array}$ & $\begin{array}{l}5.127 \\
4.633 \\
0.494 \\
0.086\end{array}$ & $\begin{array}{l}5.261 \\
4.859 \\
0.402 \\
0.076\end{array}$ \\
\hline
\end{tabular}




\begin{tabular}{|c|c|c|c|c|c|c|}
\hline 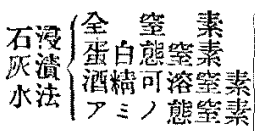 & $\begin{array}{l}5.286 \\
4.515 \\
0.771 \\
0.124\end{array}$ & $\begin{array}{l}5.542 \\
4.636 \\
0.906 \\
0.137\end{array}$ & $\begin{array}{l}5.400 \\
4.614 \\
0.786 \\
0.116\end{array}$ & $\begin{array}{l}5.220 \\
4.328 \\
0.892 \\
0.089\end{array}$ & $\begin{array}{l}\mathbf{5 . 4 5 3} \\
4.577 \\
0.876 \\
0.087\end{array}$ & $\begin{array}{l}5.276 \\
4.097 \\
1.179 \\
0.152\end{array}$ \\
\hline
\end{tabular}

\section{期白の部}

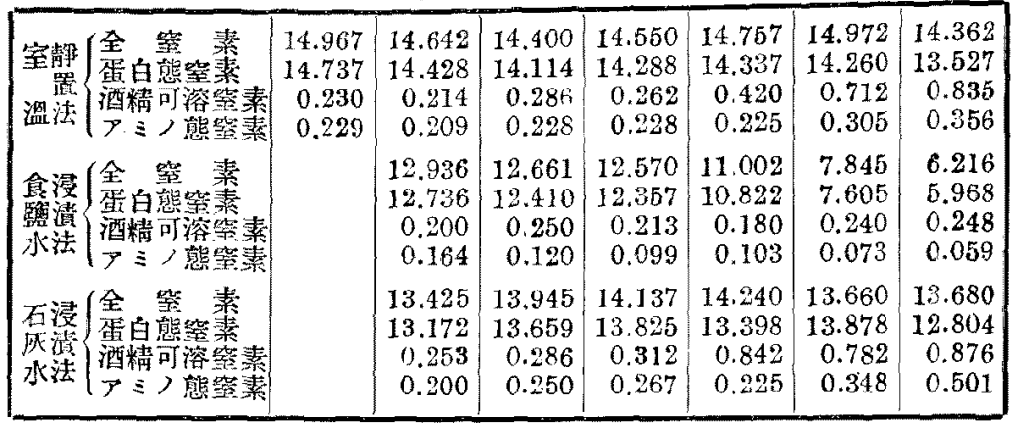

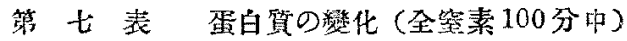

明益の部

\begin{tabular}{|c|c|c|c|c|c|c|c|}
\hline 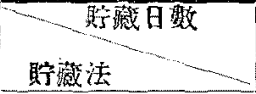 & 對照值 & 15 & 30 & 45 & 60 & 75 & 90 \\
\hline 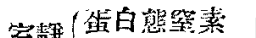 & 85.41 & 85.23 & 85.05 & 86.78 & 85.80 & 83.14 & 75.45 \\
\hline 工置 $\{$ 酒精可溶筑素 & 14.59 & 14.77 & 14.95 & 13.22 & 14.20 & 17.86 & 24.55 \\
\hline 溫法 & 2.13 & 1.72 & 2.12 & 2.14 & 2.01 & 2.49 & 4.41 \\
\hline 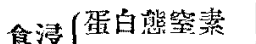 & & 87.93 & 88.31 & 86.93 & 86.81 & 90.36 & 92.36 \\
\hline 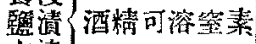 & & 12.07 & 11.69 & 13.07 & 13.19 & 9.64 & 7.64 \\
\hline 水法 & & 2.16 & 3.15 & 1.82 & 2.00 & 1.68 & 1.44 \\
\hline 石浸 |蛋白態空素 & & 85.41 & 83.65 & 85.44 & 82.91 & 83.94 & 77.65 \\
\hline 灰涉 酒精可溶熒素 & & 14.59 & 16.35 & 14.56 & 17.09 & 16.06 & 22.35 \\
\hline 水法|フミつ態紫素 & & 2.75 & 2.47 & 2.15 & 1.70 & 1.60 & 2.88 \\
\hline
\end{tabular}

的白の部

\begin{tabular}{|c|c|c|c|c|c|c|c|}
\hline 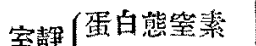 & 98.46 & 98.54 & 98.01 & 98.20 & 97.15 & 95.24 & 94.19 \\
\hline 置 酒精可溶筑素 & 1.54 & 1.46 & 1.99 & 1.80 & 2.85 & 4.76 & 5.81 \\
\hline 法|つミノ賏唯素 & 1.53 & 1.53 & $\mathbf{1}, 56$ & 1.57 & 1.52 & 2.04 & 2.48 \\
\hline 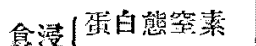 & & 98.45 & 98.02 & 98,31 & 98.36 & 96.94 & 96.01 \\
\hline 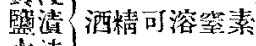 & & 1.55 & 1.98 & 1.69 & 1.64 & 3.06 & 3.99 \\
\hline 水法 & & 1.87 & 0.95 & 0.79 & 0.94 & 0.93 & 0.95 \\
\hline 石浸 (蛋白癿穻等 & & 98.12 & 97.95 & 97.79 & 91.09 & 94.28 & 93.60 \\
\hline 灰海 $\{$ 酒精可溶紫素 & & 1.88 & 3.05 & 2.21 & 5.91 & 5.72 & 6.40 \\
\hline 水法、アミノ態紫素 & & 1.49 & 1.79 & 1.89 & 1.58 & 2.55 & 3.66 \\
\hline
\end{tabular}




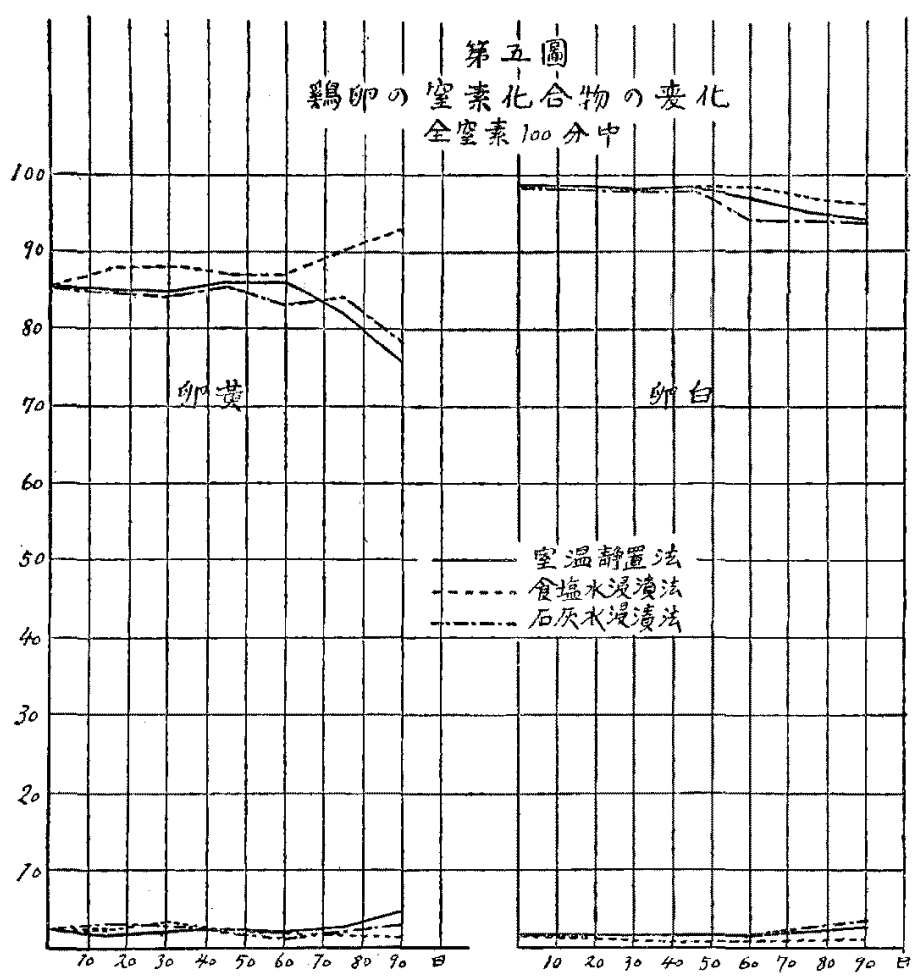

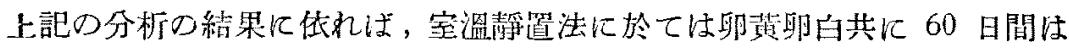

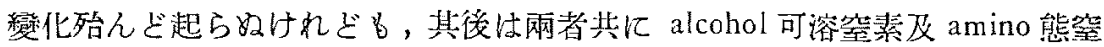
素を塯加するを以て，蛋白筫の分解せること走示す。粘度は之と並行して減 ボることは前訅の如くである。

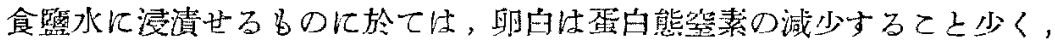

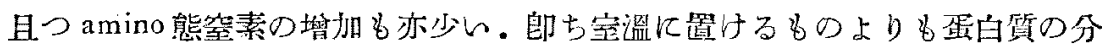

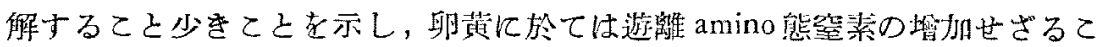
とにより蛋白質の分解尤さることが知られる。分析成績に於て alcohol 可溶

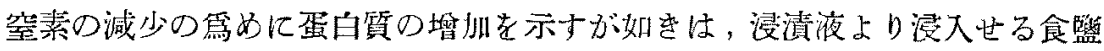
の影響によりて alcohol 可溶空素化合物が不溶解となれるに依るもの上認め られる。又，卵台の部に於て固形物巾の全空素の含量減少せるは，外部より

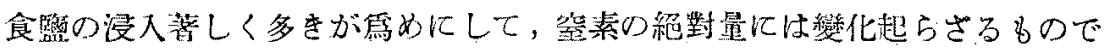


ある。

石灰水に浸漬せるものは，卵畟卵白共に食監水に浸清せるbのよりも alcohol 可溶空素及 amino 態空素の㙕抈するとと多く, 蛋白質の分解多をこと を示す。

孰れの場合に於ても，amino 態窒素は alcohol 可溶空素の睤減より10日乃 至20日後れて增減を示して居る。

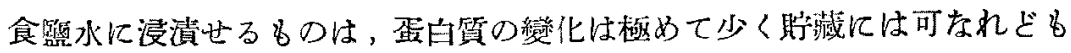

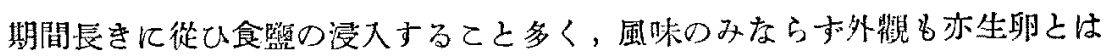

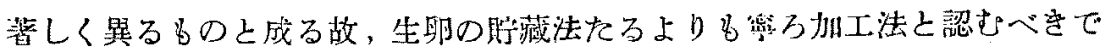
ある。

\section{E）含燐化合物の變化}

卵㽞には含燐蛋白質及 phosphatide の如き有機化合物の外に焎機態の燐酸 整が存在する。有機合燐化合物は分解すれば終には算機態の含燐化合物を生

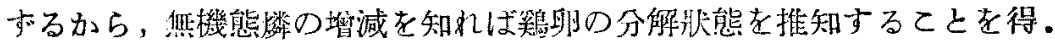

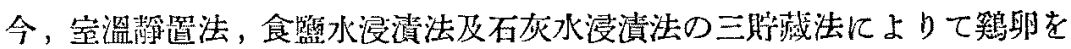
䝪藏する間に各種含燐化合物の堙減を定量したる成績を示せば，第八表，第 北表及第六圖の通りである。

筹入表合燐化合物の變化 (固形物 100 分中)

畉兴 の部

\begin{tabular}{|c|c|c|c|c|c|c|c|c|}
\hline \multicolumn{2}{|c|}{ 貼藏法 } & 對照值 & 15 & 30 & 45 & 60 & 75 & 90 \\
\hline \multirow{5}{*}{$\begin{array}{l}\text { 室 } \\
\text { 㳑 } \\
\text { 哮承 } \\
\text { 置 } \\
\text { 法 }\end{array}$} & 全 & 0.992 & 1.002 & 1.193 & 0.979 & 1.122 & 0.845 & 0.956 \\
\hline & 蛋白態燐 & 0.512 & 0.499 & 0.531 & 0.451 & 0.543 & 0.302 & 0.433 \\
\hline & 非蛋白佶燐 & 0.480 & 0.503 & 0.662 & 0.528 & 0.579 & 0.543 & 0.523 \\
\hline & 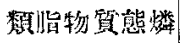 & 0.448 & 0.473 & 0.634 & 0.504 & 0.510 & 0.508 & 0.481 \\
\hline & 無留態燐 & 0.032 & 0.030 & 0.028 & 0.624 & 0.039 & 0.035 & 0.042 \\
\hline \multirow{5}{*}{ 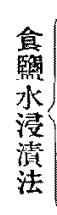 } & 全 & & 1.014 & 0.950 & 0.987 & 1.000 & 1.240 & 1.128 \\
\hline & 蛋白聲燐 & & 0.492 & 0.453 & 0.482 & 0.483 & 0.614 & 0.548 \\
\hline & 非蛋白態燐 & & 0.522 & 0.497 & 0.505 & 0.517 & 0.626 & 0.580 \\
\hline & 数脂物筫態燐 & & 0.498 & 0.465 & 0.473 & 0.488 & 0.598 & 0.558 \\
\hline & 無譏態裁 & & 0.024 & 0.032 & 0.032 & 0.029 & 0.028 & 0.022 \\
\hline
\end{tabular}




\begin{tabular}{|c|c|c|c|c|c|c|c|c|}
\hline 不 & 䗢 & & 0.956 & 0.908 & 0.904 & 1.097 & 1.142 & 1.167 \\
\hline 成 & 蛋白態橉 & & 0.599 & 0.534 & 0.457 & 0.638 & 0.569 & 0.572 \\
\hline 水 & 非蛋白態燐 & & 0.357 & 0.374 & 0.447 & 0.459 & 0.573 & 0.595 \\
\hline 清 & 数脂物筫態燐 & & 0.330 & 0.345 & 0.417 & 0.432 & 0.540 & 0.555 \\
\hline 法 & 热機態燐 & 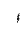 & 0.027 & 0.029 & 0.028 & 0.037 & 0.039 & 0.040 \\
\hline
\end{tabular}

卵白の部

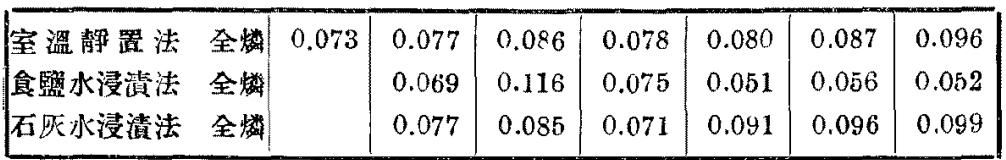

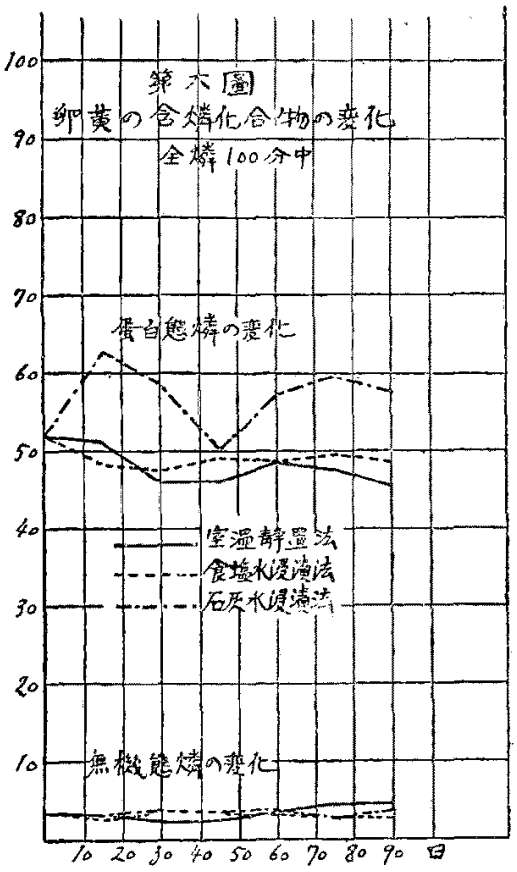

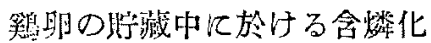
合物の變化㤌蛋白質の變化の如 〈著しからざれども，蛋白算の 變化と同䓇の傾向索示し，蛋白 態空菜の垣減已共に蛋白態燐の 堵減を示す。

上記 3 質藏法を比較すれば， 宝淄に置气たるるが最当分解 多く，食監水に浸漬せるものは 鉴化極めて少く，類脂物質態燐 は㱠んど變化索し，但し石灰水 浸漬法のものが常に類脂物劕態 燐の少き值を示すはアルカリの 影䠹上認められる。

\section{F）食監の㙞減}

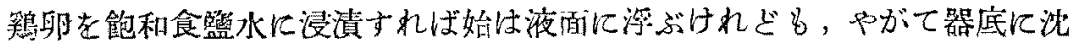

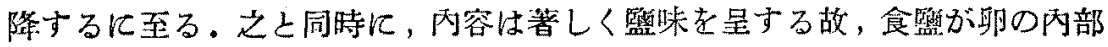

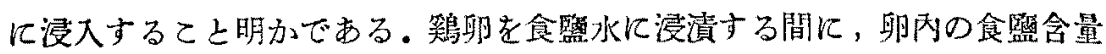
の增加することを示せば，第十表の通りである。 


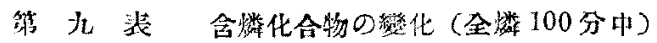

射兴 Ф部

\begin{tabular}{|c|c|c|c|c|c|c|c|c|}
\hline \multicolumn{2}{|c|}{ 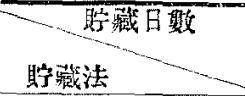 } & 龇照值 & 15 & 30 & 45 & 60 & 75 & 90 \\
\hline \multirow{4}{*}{$\begin{array}{l}\text { 室 } \\
\text { 潈 } \\
\text { 清 } \\
\text { 置 } \\
\text { 法 }\end{array}$} & 蛋白態燐 & 51,61 & 50.74 & 46.21 & 46.10 & 48.40 & 47.58 & 45.30 \\
\hline & 非蛋白態燐 & 48.39 & 49.26 & 53.79 & 53.90 & 51.60 & 52.42 & 54.70 \\
\hline & 類脂物質萑橉 & 45.16 & 46.27 & 51.44 & 51.45 & 48.13 & 48.28 & 50.33 \\
\hline & 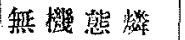 & 3.20 & 2.99 & 2.35 & 2.45 & 3.47 & 4.14 & 4.37 \\
\hline \multirow{3}{*}{ 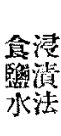 } & 蛋白態糙 & & 48.42 & 47.68 & 48.86 & 48.30 & 49.54 & 48.15 \\
\hline & 非蛋白態繎 & & 51.58 & 52.32 & 51.14 & 51.70 & 50.46 & 51.85 \\
\hline & 類脂物質態烧 & & 49.21 & 48.95 & 47.90 & 48.80 & 4820 & 49.50 \\
\hline & 無 機 態 䗲 & & 2.37 & 3.37 & 3.24 & 2.90 & 2.26 & 2.35 \\
\hline \multirow{4}{*}{$\begin{array}{l}\text { 石浸 } \\
\text { 灰清 } \\
\text { 水法 }\end{array}$} & 蛋白態燐 & & 62.66 & 58.81 & 50.55 & 57.90 & 59.83 & 57.97 \\
\hline & 非蛋白態橉 & & 37.34 & 41.19 & 49.45 & 42.10 & 40.17 & 42.03 \\
\hline & 颣脂物筫態烧 & & 34.52 & 38.00 & 46.35 & 38.73 & 37,28 & 38.63 \\
\hline & 烸機 咟 燐 & & 2.82 & 3.19 & 3.10 & 3.37 & 2.89 & 3.40 \\
\hline
\end{tabular}

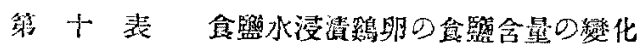

(固形物 100 分中)

\begin{tabular}{|c|c|c|c|c|c|c|c|c|}
\hline 浸 & 数 & 0 & 15 & 30 & 45 & 60 & 75 & 90 \\
\hline 畉 & 橫 & 0.03 & 0.29 & 0.29 & 0.53 & I. 22 & 2.13 & 2.88 \\
\hline 卵 & 白 & 1.16 & 2.29 & 9.79 & 12.69 & 18.92 & 19.33 & 21.37 \\
\hline
\end{tabular}

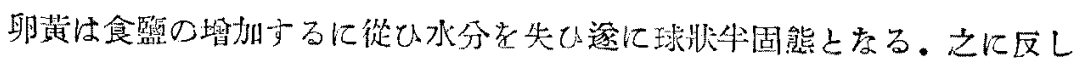

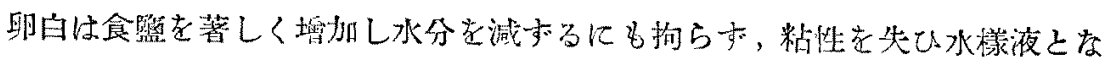
る.

\section{G）石灰の增減}

筑鳥卯支食監水又は石灰水汇浸漬中に，石灰が浸漬液より浸大寸るか又は卵

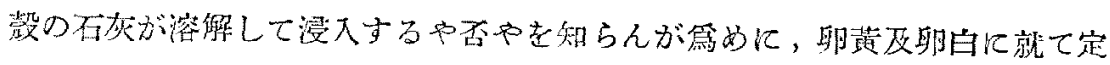
量したる絬果は次の裴に示す通りである。

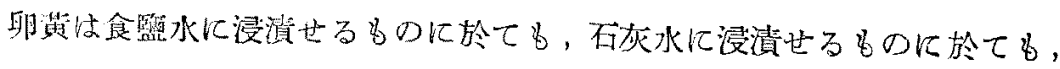
石灰の含量に殆んに゙變化を認め亦。

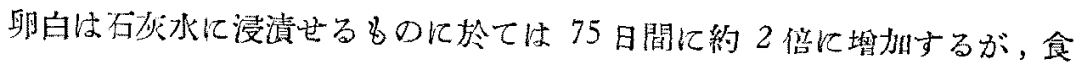




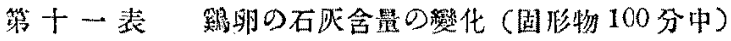

射黃 D 部

\begin{tabular}{|c|c|c|c|c|c|c|c|}
\hline 浸清法 & 0 & 15 & 30 & 45 & 60 & 75 & 90 \\
\hline 㝨監水浸清法 & 0.33 & 0.32 & 0.31 & 0.27 & 0.32 & 0.33 & 0.29 \\
\hline 石压水浸㮰法 & & 0.27 & 0.34 & 0.29 & 0.34 & 0.34 & 0.33 \\
\hline
\end{tabular}

町白 $の$ 部

\begin{tabular}{|l|l|l|l|l|l|l|l|}
\hline 食監水浸瀆法 & 0.08 & 0.07 & 0.14 & 0.12 & 0.11 & 0.23 & 0.28 \\
石灰水浸涉法 & & 0.07 & 0.08 & 0.08 & 0.10 & 0.14 & 0.18 \\
\hline
\end{tabular}

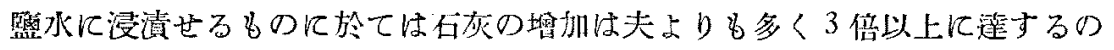

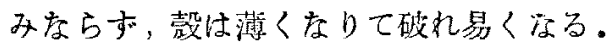

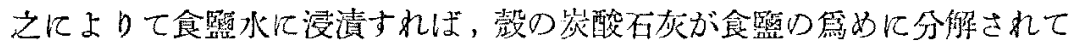

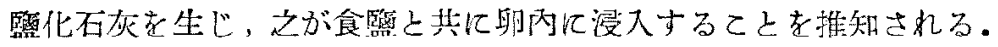

第三 試驗結果の考察

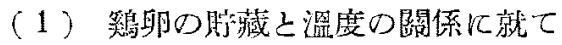

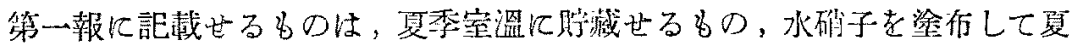

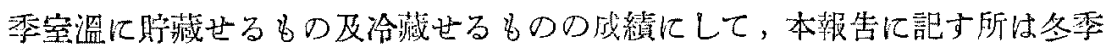
宝溫に質藏せるるのでする。

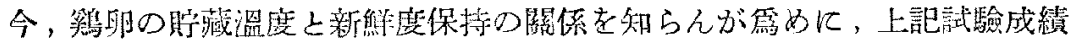

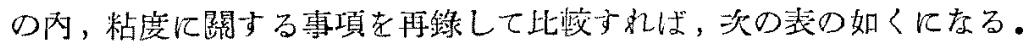

\section{第十二表䳩期の粘度に對す万睦藏溫度の影響 (新鮮卶の粘度去 100 とす)}

莭黄 $の$ 部

\begin{tabular}{|c|c|c|c|c|c|c|c|c|c|c|c|c|c|c|}
\hline 眝藏法 & 0 & 10 & 15 & 20 & 80 & 40 & 45 & 50 & 60 & 70 & 75 & 80 & 90 & 100 \\
\hline 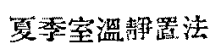 & 100 & 67 & - & 51 & 51 & 43 & - & 33 & 24 & 18 & - & 31 & - & 12 \\
\hline 夏李水确子法 & & - & - & 72 & 61 & 44 & - & 40 & 34 & 37 & - & 30 & - & 11 \\
\hline 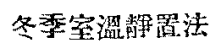 & & - & 102 & - & 58 & - & 47 & 一 & 35 & - & 37 & - & 21 & - \\
\hline 冷 藏法法 & & 86 & - & 82 & 78 & 76 & - & 78 & - & - & - & - & - & - \\
\hline
\end{tabular}


率白 口部

\begin{tabular}{|c|c|c|c|c|c|c|c|c|c|c|c|c|c|c|}
\hline 夏季室濯静置法 & 100 & 69 & - & 40 & 34 & 32 & - & 48 & 48 & 32 & - & 36 & - & 18 \\
\hline 要季水碓子法 & & 82 & - & 100 & 82 & 82 & - & 75 & 49 & 50 & - & 48 & - & 36 \\
\hline 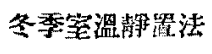 & & - & 69 & - & 70 & - & 50 & - & 74 & - & 61 & - & 49 & - \\
\hline 冷 藏 法 & & 87 & - & 83 & 84 & 93 & - & 86 & 82 & - & - & - & - & - \\
\hline
\end{tabular}

但し, 夏季抒藏は五月より九月に至る期間, 室溜は最低 $17^{\circ} \mathrm{C}$ 最高 $28^{\circ} \mathrm{C}$ にして大部分 $20^{\circ} \mathrm{C}$ 以上である. 冬季貯藏は十月より整年一月に至る期間， 宝溫は最低 $1.5^{\circ} \mathrm{C}$ 最㗬 $21^{\circ} \mathrm{C}$ にて大部分 $12^{\circ} \mathrm{C}$ 以下である.冷藏法に於 ける溫度性 $7^{\circ} \mathrm{C}$ 乃至 $10^{\circ} \mathrm{C}$ 老保つ。

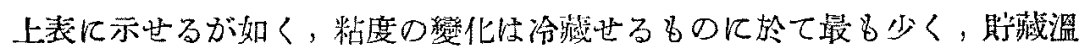
度の高きものに於て粘度の低下すること大である。例へば，卵仝に於ては 7

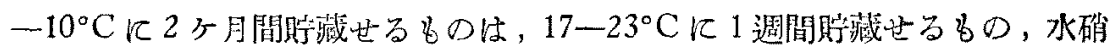

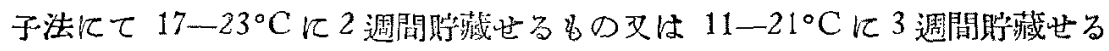

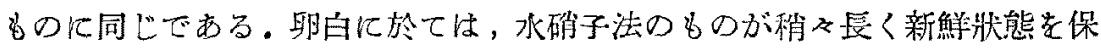
2 .

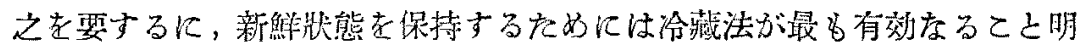

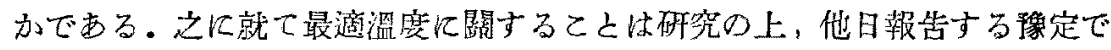
ある。

\section{（2）渗漬法に就きて}

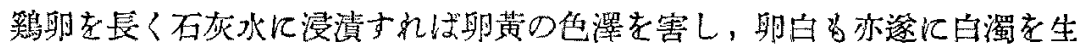
ホるに至る。而して卵は一種の石灰臭を帅で食用几適せざるに至るすのなる 故，石灰水浸清法は長期眝藏法として不適當である。

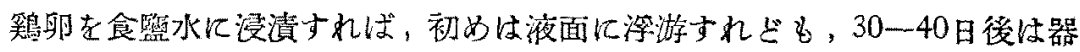

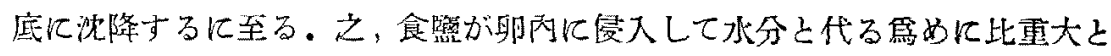

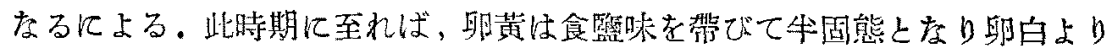

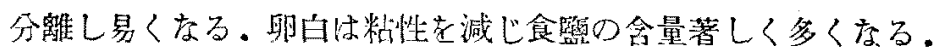

之安以て，食監水浸漬法は短期間は粘度の低減を防ぐて效あれも゙も，長期

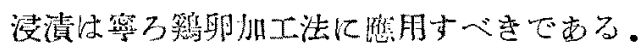


摘 要

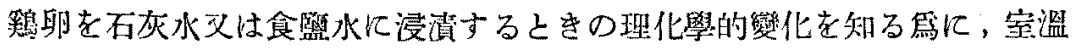

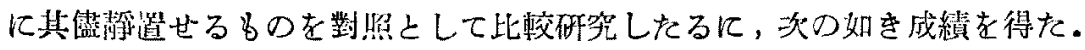

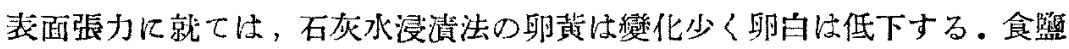
水浸漬法の卵黄は上景し卵白は低下する。

粘度に就ては，石灰水浸漬法のものは卵资卵白共に低下するが，食傿水に 浸漬せるるのの卯黃は著しく檑加し，卵白は減じて逐に水樣液となる。

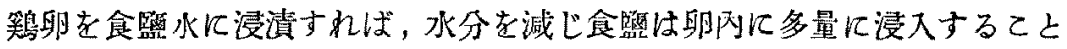
老知万。

石灰水に浸漬せるものは蛋白質の變化多くして, alcohol 可溶空素，amino

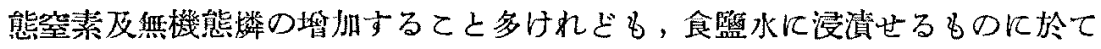
は蛋白質の分解することはない。

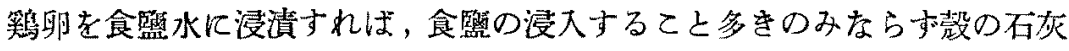
が溶解して，即冈に浸入するとと方多い，然るに，石灰水に浸清したるも のは石灰の浸入ナること割合に多からざれども，石灰臭老帶で卵黄の色澤を

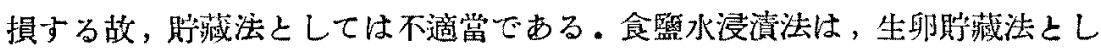
てよりる筧ろ加工法として用ふることが適當である。

（昭和 3-4 年實驗） 